\title{
Article \\ Investigation of Microbial Hydrolysis of Hen Combs with Bacterial Concentrates
}

\author{
Oksana Zinina ${ }^{1, *(\mathbb{D})}$, Svetlana Merenkova ${ }^{1}\left(\mathbb{D}\right.$, Maksim Rebezov $^{2} \mathbb{D}$, Gulnara Zhumanova ${ }^{3}$, Pavel Burkov $^{4}(\mathbb{D}$ \\ and Alexandra Knyazeva ${ }^{2}$
}

check for updates

Citation: Zinina, O.; Merenkova, S.; Rebezov, M.; Zhumanova, G.; Burkov, P.; Knyazeva, A. Investigation of Microbial Hydrolysis of Hen Combs with Bacterial Concentrates.

Fermentation 2022, 8, 56. https:// doi.org/10.3390/fermentation8020056

Academic Editor: Chrysoula Tassou

Received: 31 December 2021

Accepted: 26 January 2022

Published: 28 January 2022

Publisher's Note: MDPI stays neutral with regard to jurisdictional claims in published maps and institutional affiliations.

Copyright: (C) 2022 by the authors. Licensee MDPI, Basel, Switzerland. This article is an open access article distributed under the terms and conditions of the Creative Commons Attribution (CC BY) license (https:// creativecommons.org/licenses/by/ $4.0 /)$.
1 Department of Food and Biotechnology, South Ural State University (National Research University), 76 Lenin Avenue, 454080 Chelyabinsk, Russia; merenkovasp@susu.ru

2 Laboratory of Scientific and Methodological Work and Control and Analytical Research, V. M. Gorbatov Federal Research Center for Food Systems of Russian Academy of Sciences, 26 Talalikhina St., 109316 Moscow, Russia; rebezov@ya.ru (M.R.); a.knyazeva@fncps.ru (A.K.)

3 Engineering and Technology Faculty, Shakarim University, 20a Glinka Str., Semey 071412, Kazakhstan; g-7290@mail.ru

4 Center for Biotechnology of Animal Reproduction, South Ural State Agrarian University, 13 Gagarin Str., 457100 Troitsk, Russia; burcovpavel@mail.ru

* Correspondence: zininaov@susu.ru; Tel.: +7-906-871-36-81

\begin{abstract}
When slaughtering and processing poultry, large quantities of meat by-products are generated; therefore, the development of the newest methods for processing secondary raw materials is an urgent problem. Animal proteins have relevant technological applications and are also considered as a potential source of bioactive peptides. Current technologies suggested that protein substances can be isolated from meat co-products through microbial hydrolysis. The purpose of the study was to optimize the technological parameters of microbial hydrolysis of hen combs and to analyze the modification of the microstructure and properties of hydrolyzed by-products under the action of bacterial enzymes. Hen's combs were hydrolyzed by bifidobacteria and concentrated Propionix liquid. A multifactorial experiment was used to determine the optimal conditions for the hydrolysis process. As a result of the study, multiple regression equations and response surfaces were obtained, which describe the process of hydrolysis of hen combs to identify the optimal hydrolysis parameters. Temperature, amount of bacterial concentrate and hydrolysis period are factors that have a significant impact on the degree of hydrolysis. The results of microscopic and dispersed analysis confirm the good hydrolyzability of combs due to changes in structural components and an increase in the amount of smaller protein particles.
\end{abstract}

Keywords: by-product; fermentation; propionic acid bacteria; bifidobacteria; comb; multiple regression equation

\section{Introduction}

Large amounts of meat by-products are generated during slaughtering and poultry processing, and these products require rational and ecological management. Innovative developments allow creating ingredients with high added-value from chicken by-products with the least environmental impact, handling and disposal costs.

The most valuable component of raw meat materials are proteins. In this way, byproduct and waste from meat processes can be collected as a source of proteins [1,2]. Some proteins of animal origin have relevant technological applications to form the structure of food systems, for binding water, gelation, foaming and emulsification, while protein hydrolyzates may contribute to a better digestibility and taste quality of food [3,4]. Protein hydrolyzates from meat by-products are considered as a potential source of flavorenhancing ingredients [5]. During protein hydrolysis products with physiological effects 
can be generated, such as bioactive peptides for applications in the food, pharmaceutical and cosmetics industry [6]. The major bioactivities of peptides are antihypertensive, antioxidant, antithrombotic, and antimicrobial [7-9].

Current technologies suggest that bioactive substances can be created from by-product through enzymatic hydrolysis $[10,11]$. Proteins from meat by-product are hydrolyzed with proteolytic enzymes under controlled parameters to generate bioactive peptides. Scientific substantiation of the effectiveness of the commercial enzymes application for protein hydrolysis has been made, such as pepsin, trypsin, chymotrypsin and papain, and also enzymes from microbial origin such as neutrase and alcalase [6,11,12]. In previous studies, we have proved the possibility of hydrolysis of meat raw materials and by-products with bacterial concentrates. The advantages of using bacterial starter cultures in comparison with individual enzymes are the better adaptation of microbial enzymes to different environments, as well as the accumulation of biologically valuable ingredients of bacterial metabolism in hydrolysates [13,14].

Exopeptidases and endopeptidases can release large protein fragments and polypeptides, but they also contribute to the production of individual peptides and free amino acids. Peptides with sequences between 2 and 20 amino acids give the most bioactivity and therefore, the main technological problems are associated with obtaining the hydrolyzates, containing peptides with low molecular weight [15].

When fermenting poultry by-products with microbial enzymes, an important issue is the development of rational process conditions for obtaining low-molecular-weight hydrolysates of animal protein. By changing such fermentation parameters as the hydrolysis period, the temperature and the concentration of microorganisms, it is possible to regulate the yield and properties of the final product. Mathematical modeling is a modern method for optimizing biotechnological processes $[11,16]$.

The purpose of the study was to optimize the technological parameters of microbial hydrolysis of hen combs and to analyze the modification of the microstructure and properties of hydrolyzed by-products under the action of bacterial enzymes.

\section{Materials and Methods}

\subsection{Raw Materials and Ingredients}

The combs were obtained by slaughtering 300 hens of the parent stock at the age of 11 months (average weight $4 \mathrm{~kg}$ ). The combs were manually removed from the heads, washed, packaged in plastic bags and frozen at $-18{ }^{\circ} \mathrm{C}$. Frozen combs were transported in a refrigerator to the laboratory of the Food and Biotechnology Department within $2 \mathrm{~h}$ for further processing. The proximate composition of the combs (\%): moisture content-71.82; protein content-14.81; fat content-10.47; ash content-1.26.

Sterilized cheese whey was used to treat the combs. The proximate composition of the cheese whey (\%): moisture content-93.12; protein content-0.96; fat content -0.37 ; ash content- 0.61 .

The following bacterial concentrates produced by Propionix company (Moscow, Russia), were used for biotechnological processing of hen combs:

Bifidobacteria liquid concentrate (BLC) is a concentrated microbial mass of the Bifidobacterium longum B379M strain with an activity of $10^{11}-10^{12} \mathrm{CFU} / \mathrm{cm}^{3}$.

Propionix liquid concentrated starter culture (Propionix LCSC) is a concentrated microbial mass of the Propionibacterium freudenreichii subsp strain shermanii-KM 186, the bacteria of which are in the active form $-10^{10}-10^{11} \mathrm{CFU} / \mathrm{cm}^{3}$.

\subsection{Biotechnological Treatment of the Combs}

Hen's combs chopped in a meat grinder (Binatone, MFP 076) were defatted three times with a mixture of chloroform: methanol (2:1), shaking for $2 \mathrm{~h}$. Sterilized cheese whey was added to the defatted mass of the combs in a ratio of 1:8 and homogenized (Stegler DG-360). To produce the experimental samples, liquid concentrates of bacteria were added to the obtained homogenates in an amount of $5 \%, 10 \%$, and $15 \%$ to the mass of the combs and 
thoroughly mixed. The control sample of the homogenate did not contain the bacterial concentrate. The homogenates were hydrolyzed in a thermostat for $12 \mathrm{~h}$ at temperatures of 30,35 , and $40^{\circ} \mathrm{C}$.

\subsection{Optimization of Hydrolysis}

A multifactorial experiment was used to determine the optimal conditions for the hydrolysis process.

The multiple regression equation and the response surface methodology were used to determine the optimal values of independent variables. The change in the variable, the degree of hydrolysis (DH), was evaluated under the effect of three factors: $X_{1}$-temperature (30-40 ${ }^{\circ} \mathrm{C}$ in $5{ }^{\circ} \mathrm{C}$ steps); $\mathrm{X}_{2}$ - the amount of bacterial concentrate (5-15\% in $5 \%$ steps); $\mathrm{X}_{3}$ the hydrolysis period ( $4-12 \mathrm{~h}$ in $4 \mathrm{~h}$ steps). A total of 17 runs were proposed in this model, including three replicas at the central point.

The degree of hydrolysis (DH, \%) was calculated by the formula:

$$
\mathrm{DH}=\left(\frac{\mathrm{N}_{\mathrm{AA}}-\mathrm{N}_{\mathrm{AA} 0}}{\mathrm{~N}_{\mathrm{OA}}-\mathrm{N}_{\mathrm{AA} 0}}\right) \times 100 \%
$$

where $\mathrm{N}_{\mathrm{OA}}$ - content of total nitrogen, \%; $\mathrm{N}_{\mathrm{AA} 0}$ - amine nitrogen in the non-hydrolyzed combs, \%; $\mathrm{N}_{\mathrm{AA}}$ - the content of amine nitrogen in the hydrolysate after hydrolysis for a certain period of time, $\%$.

The content of total nitrogen, amine nitrogen in the non-hydrolyzed combs and the resulting hydrolysates was determined by the biuret method.

Effect of independent variables on the dependent variable $(\mathrm{DH})$ was analyzed using MathCAD (PTC:order \#2456861 \#2497812). The following indicators of the obtained multiple regression equation were determined: regression coefficients, the reliability of the equation by the coefficient of determination $\left(R_{2}\right)$ and Fisher's criterion (Fkr), the statistical significance of the parameters of the multiple regression equation by the Student's test $(\mathrm{t})$. The partial correlation coefficient $(\beta)$ was calculated to assess the validity of including independent variables in the regression model.

In general, the equation of the three-factor experiment looks like this:

$\mathrm{Y}=\mathrm{b}_{0}+\mathrm{b}_{1} \cdot \mathrm{X}_{1}+\mathrm{b}_{2} \cdot \mathrm{X}_{2}+\mathrm{b}_{3} \cdot \mathrm{X}_{3}+\mathrm{b}_{12} \cdot \mathrm{X}_{1} \cdot \mathrm{X}_{2}+\mathrm{b}_{13} \cdot \mathrm{X}_{1} \cdot \mathrm{X}_{3}+\mathrm{b}_{23} \cdot \mathrm{X}_{2} \cdot \mathrm{X}_{3}+\mathrm{b}_{123} \cdot \mathrm{X}_{1} \cdot \mathrm{X}_{2} \cdot \mathrm{X}_{3}+\mathrm{b}_{11} \cdot \mathrm{X}_{1}{ }^{2}+b_{22} \cdot \mathrm{X}_{2}{ }^{2}+b_{33} \cdot \mathrm{X}_{3}^{2}$

\subsection{Determination of Chemical Properties}

The titrated acidity and the active acidity in the hydrolysates were analyzed in dynamics after $0,4,8$ and 12 h of hydrolysis. The active acidity was measured on a portable pH-meter (HANNA HI83141). The titrated acidity was analyzed by neutralizing the hydrolysate solution (in a ratio of 1:5 with water) with $0.1 \mathrm{~N} \mathrm{NaOH}$, the values were expressed in degrees of lactic acid.

\subsection{Determination of Free Amino Acids in Comb Hydrolysates}

The content of unbound (free) amino acids was determined on an Agilent 1260 Infinity LC liquid chromatograph using a C18 PA column $(3.5 \mu \mathrm{m}, 4.6 \mathrm{~mm} \times 150 \mathrm{~mm}, \mathrm{ZORBAX})$ as the stationary phase. The following were used as the mobile phase: A-acetonitrile: methanol: water (45:45:10); C-pH 8.2, Na2HPO4 $1.42 \mathrm{~g}$, and Na2B4O7 $2.1 \mathrm{~g}$. Samples were prepared by liquid extraction with preliminary addition of $20 \%$ trichloroacetic acid to precipitate proteins and peptides. After adding acidified hydrochloric acid buffer with pH 2.2 and holding the homogenate under cooling conditions, the mixture was centrifuged (20 $\mathrm{min}, 4^{\circ} \mathrm{C}, 10,000 \mathrm{~g}$ ) and the supernatant was passed through a syringe filter into a vial.

Orthophthalaldehyde was used as derivatizing agents for primary amino acids and 9-fluoromethyl chloroformate for secondary amino acids.

The content of free amino acids was expressed in units: mg of AA per $100 \mathrm{~g}$ of liquid hydrolyzates. 


\subsection{Determination of the Dispersed Composition}

The study of the dispersed composition and the analysis of the particle size in the hydrolysates samples were carried out by the method of laser dynamic light scattering on a laser diffraction analyzer Microtrac S3500.

\subsection{Investigation of Microstructure}

For microstructural analysis, the fermented by-products were kept in a $40 \%$ formalin solution for $72 \mathrm{~h}$ to hardening the consistency. The microstructure modification of comb's hydrolyzates during biotechnological processing was studied by microscopy of stained histopreparations using a microscope LEICA DMRXA (Germany, Wetzlar). The sections of the samples were stained with hematoxylin-eosin and picro-fuchin according to the Van Gieson method. Using a digital video camera LEICA DFC 290 (Germany, Wetzlar), images of micro-preparations were obtained in the format of graphic TIFF files in the RGB colour space.

\subsection{Statistical Analysis}

Analyses were performed in five replicates, and each measurement was repeated three times. Results were expressed as the mean values of the five replicates \pm the standard deviation. Probability values of $p \leq 0.05$ were taken to indicate statistical significance. The data were analysed via one-way ANOVA analysis of variance using the free web-based software offered by Assaad et al. [17].

\section{Results and Discussion}

\subsection{Optimization of Hydrolysis}

Hydrolyzates with a high degree of hydrolysis (DH) and yield are obtained during enzymatic hydrolysis of waste and by-product $[16,18]$. The degree of hydrolysis (DH) characterizes the degree of enzymatic cleavage of a protein substrate peptide under the effect of various factors: hydrolysis time, reaction $\mathrm{pH}$, enzyme concentration, reaction temperature [19].

The multiple regression equation and the response surface methodology were used to determine the optimal values of independent variables. The change in the variable, the degree of hydrolysis $(\mathrm{DH})$, was evaluated under the effect of three factors: temperature $\left(X_{1}\right)$, the amount of bacterial concentrate $\left(X_{2}\right)$, and the hydrolysis period $\left(X_{3}\right)$. A total of 17 runs were proposed in this model, including three replicas at the central point.

The central composite rotary structure was used to determine the optimal conditions for the process of hydrolysis (Table 1).

As a result of optimization, multiple regression equations were obtained for the hydrolysis process of the hen combs by Propionix LCSC $\left(\mathrm{DH} 1_{h}\right)$ and BLC $\left(\mathrm{DH} 2_{h}\right)$ :

$$
\begin{gathered}
\mathrm{DH} 1_{\mathrm{h}}=6.560+1.744 \cdot \mathrm{X}_{1}+0.367 \cdot \mathrm{X}_{2}+2.518 \cdot \mathrm{X}_{3}+0.387 \cdot \mathrm{X}_{1} \cdot \mathrm{X}_{3}+0.573 \cdot \mathrm{X}_{2} \cdot \mathrm{X}_{3} \\
\mathrm{DH} 2_{\mathrm{h}}=7.427+0.951 \cdot \mathrm{X}_{1}+0.283 \cdot \mathrm{X}_{2}+2.598 \cdot \mathrm{X}_{3}+0.320 \cdot \mathrm{X}_{2} \cdot \mathrm{X}_{3}
\end{gathered}
$$

where $\mathrm{X}_{1}$ is the temperature $\left({ }^{\circ} \mathrm{C}\right), \mathrm{X}_{2}$ is the amount of bacterial concentrate $(\%)$, and $\mathrm{X}_{3}$ is the hydrolysis period $(\mathrm{h})$.

The statistical significance of the equations has been proved by Student's criterion. Based on the maximum partial correlation coefficient, we conclude that the factor $\mathrm{X}_{3}$ has the most essential effect on the hydrolysis. When comparing the $p$-values within the independent variables, a high degree of reliability of the regression coefficients for the temperature $\left(X_{1}\right)(p \leq 0.001 ; p \leq 0.01)$ and the hydrolysis period $\left(X_{3}\right)(p \leq 0.001)$ was noted (Table 2). 
Table 1. Central composite rotatable design matrix showing coded and actual values of process parameters and their effects on the response variable, degree of hydrolysis $(\mathrm{DH})$.

\begin{tabular}{|c|c|c|c|c|c|}
\hline \multirow[b]{2}{*}{ Run } & \multirow[b]{2}{*}{$X_{1}$} & \multirow[b]{2}{*}{$X_{2}$} & \multirow[b]{2}{*}{$X_{3}$} & \multicolumn{2}{|c|}{ DH of Hen Combs } \\
\hline & & & & Propionix LCSC & BLC \\
\hline 1 & $30(-1)$ & $5(-1)$ & $4(-1)$ & 1.9 & 3.9 \\
\hline 2 & $30(-1)$ & $15(+1)$ & $4(-1)$ & 1.9 & 3.3 \\
\hline 3 & $30(-1)$ & $5(-1)$ & $12(+1)$ & 7.1 & 9.1 \\
\hline 4 & $30(-1)$ & $15(+1)$ & $12(+1)$ & 9.1 & 13.1 \\
\hline 5 & $40(+1)$ & $5(-1)$ & $4(-1)$ & 5.7 & 4.0 \\
\hline 6 & $40(+1)$ & $15(+1)$ & $4(-1)$ & 3.3 & 3.9 \\
\hline 7 & $40(+1)$ & $5(-1)$ & $12(+1)$ & 11.5 & 12.3 \\
\hline 8 & $40(+1)$ & $15(+1)$ & $12(+1)$ & 15.7 & 12.4 \\
\hline 9 & $35(0)$ & $10(0)$ & $8(0)$ & 4.5 & 9.1 \\
\hline 10 & $35(0)$ & $10(0)$ & $8(0)$ & 4.3 & 8.9 \\
\hline 11 & $35(0)$ & $10(0)$ & $8(0)$ & 4.8 & 9.3 \\
\hline 12 & $48.6(1,2154)$ & $10(0)$ & $8(0)$ & 11.6 & 13.0 \\
\hline 13 & $23.5(-1,2154)$ & $10(0)$ & $8(0)$ & 3.4 & 3.9 \\
\hline 14 & $35(0)$ & $18.2(1,2154)$ & $8(0)$ & 5.9 & 5.9 \\
\hline 15 & $35(0)$ & $3.9(-1,2154)$ & $8(0)$ & 4.5 & 5.2 \\
\hline 16 & $35(0)$ & $10(0)$ & $14.6(1,2154)$ & 9.1 & 9.1 \\
\hline 17 & $35(0)$ & $10(0)$ & $3.1(-1,2154)$ & 3.2 & 3.2 \\
\hline
\end{tabular}

Table 2. Results of statistical analysis of regression coefficients for independent variables $(\mathrm{Xj})$ during hydrolysis of hen combs.

\begin{tabular}{|c|c|c|c|c|c|c|}
\hline \multirow[b]{2}{*}{ Variables } & \multicolumn{3}{|c|}{ Hydrolyzing by Propionix LCSC } & \multicolumn{3}{|c|}{ Hydrolyzing by BLC } \\
\hline & $\begin{array}{l}\text { Regression } \\
\text { Coefficient (b) }\end{array}$ & $\begin{array}{l}t \text {-Student's } \\
\text { Criterion }\end{array}$ & $p$-Value & $\begin{array}{l}\text { Regression } \\
\text { Coefficient (b) }\end{array}$ & $\begin{array}{l}t \text {-Student's } \\
\text { Criterion }\end{array}$ & $p$-Value \\
\hline Y-intersection & 6.560 & 89.607 & $p \leq 0.001$ & 7.427 & 125.009 & $p \leq 0.001$ \\
\hline Variable $\mathrm{X}_{1}$ & 1.744 & 19.127 & $p \leq 0.001$ & 0.951 & 12.845 & $p \leq 0.01$ \\
\hline Variable $\mathrm{X}_{2}$ & 0.367 & 4.046 & $p \leq 0.05$ & 0.283 & 3.829 & $p \leq 0.05$ \\
\hline Variable $X_{3}$ & 2.518 & 27.780 & $p \leq 0.001$ & 2.598 & 35.104 & $p \leq 0.001$ \\
\hline Variable $X_{1} \cdot X_{2}$ & -0.013 & -0.125 & $p \geq 0.05$ & -0.226 & -2.617 & $p \geq 0.05$ \\
\hline Variable $X_{1} \cdot X_{3}$ & 0.387 & 3.645 & $p \leq 0.05$ & 0.120 & 1.385 & $p \geq 0.05$ \\
\hline Variable $X_{2} \cdot X_{3}$ & 0.573 & 5.405 & $p \leq 0.05$ & 0.320 & 3.695 & $p \leq 0.05$ \\
\hline $\begin{array}{l}\text { Variable } \\
\mathrm{X}_{1} \cdot \mathrm{X}_{2} \cdot \mathrm{X}_{3}\end{array}$ & 0.307 & 2.891 & $p \geq 0.05$ & -0.293 & -3.387 & $p \geq 0.05$ \\
\hline Variable $X_{1}^{2}$ & 0.433 & 3.015 & $p \geq 0.05$ & 0.374 & 3.189 & $p \geq 0.05$ \\
\hline Variable $X_{2}^{2}$ & -0.019 & -0.138 & $p \geq 0.05$ & -0.197 & -1.682 & $p \geq 0.05$ \\
\hline Variable $X_{3}{ }^{2}$ & 0.167 & 1.164 & $p \geq 0.05$ & -0.079 & -0.674 & $p \geq 0.05$ \\
\hline
\end{tabular}

At the 3D response levels, the dependent variable was fixed at the central level (Z-axis), and the influence of two independent variables on the response was fixed on the $\mathrm{Y}$ and $X$ axes (Figure 1). According to the designed models of the response surface, the most optimal values of the factors were set as follows: for combs hydrolyzing by Propionix LCSC: the temperature $-41.92-43.43{ }^{\circ} \mathrm{C}$; the amount of bacterial concentrate-13.09-13.94\%; the 
hydrolysis period- $11.41 \mathrm{~h}$. With these optimal process parameters, the degree of hydrolysis can be at the level of $14.40-14.88 \%$ (Figure 1). Within the studding parameters, an increase in the yield of hydrolyzed product was observed with a cooperative increase in temperature (up to $43.43^{\circ} \mathrm{C}$ ), amount of bacterial concentrate (up to $13.94 \%$ ), and hydrolysis period (up to $11.41 \mathrm{~h}$ ). A further increase in these parameters has a less significant effect on the degree of hydrolysis.

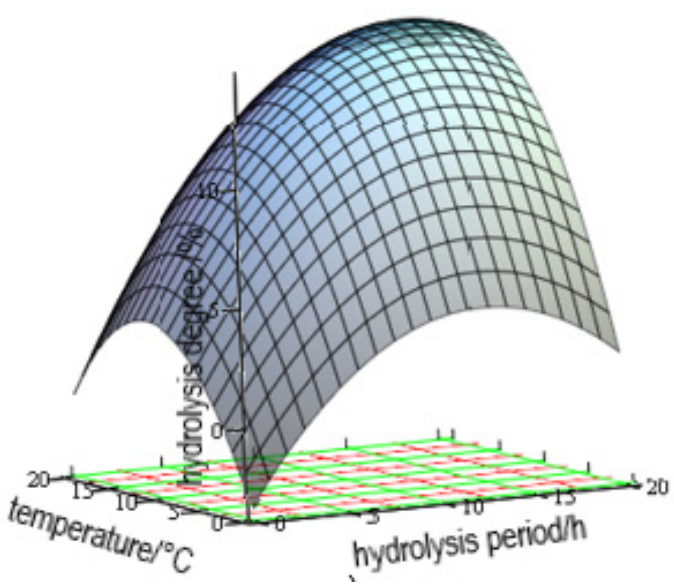

(a)

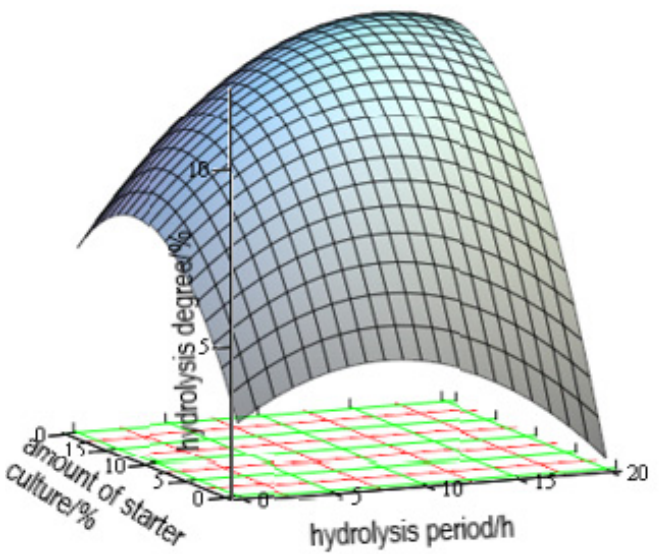

(c)

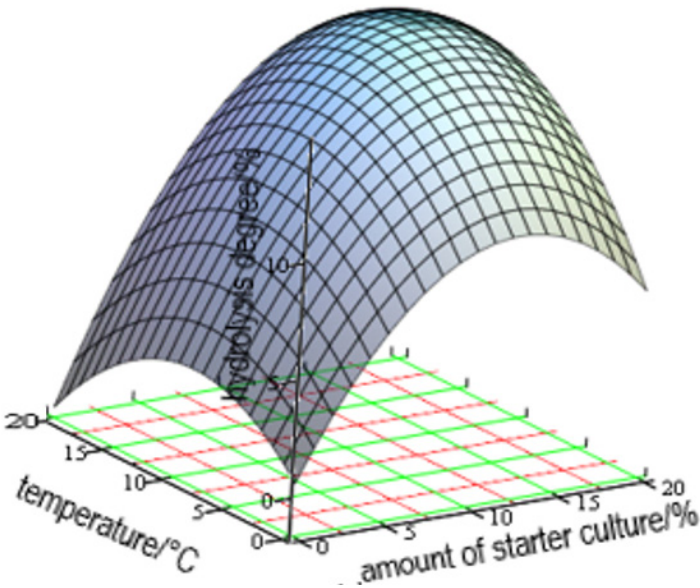

(b)

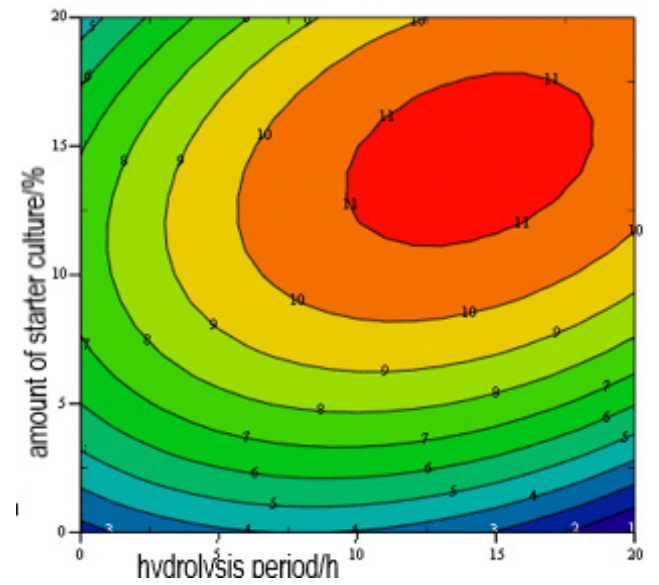

(d)

Figure 1. The 3D surface plots of hydrolysis degree of hen combs treated with Propionix LCSC as a function of factors: (a) interactions of temperature and hydrolysis period on $\mathrm{DH}$; (b) interactions of temperature and the amount of bacterial concentrate; (c) interaction of the amount of bacterial concentrate and hydrolysis period on $\mathrm{DH}$; (d) contour plots of degree of hen combs hydrolysis as a function of interaction of the amount of bacterial concentrate and hydrolysis period on $\mathrm{DH}$.

The most optimal values of the factors for hen combs hydrolyzing by BLC were set as follows: the temperature $-39.7^{\circ} \mathrm{C}$, the amount of bacterial concentrate-10.19-10.69\%, the hydrolysis period-10.04-12.29 h, the degree of hydrolysis-12.16-14.27\% (Figure 2). According to the applied methodology, we observe the correspondence of the most effective temperature and the degree of hydrolysis when comparing various reaction parameters. When analyzing the results of studying the hydrolysis of raw materials, it was noted that the degree of hydrolysis varies significantly depending on the type of by-products, enzyme activity and process parameters $[16,19,20]$. 


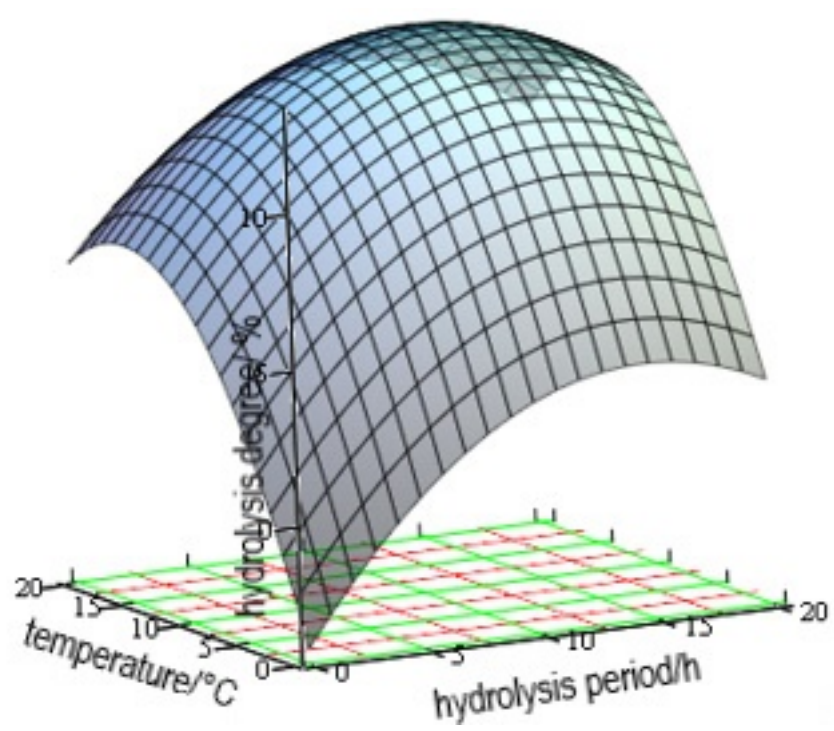

(a)

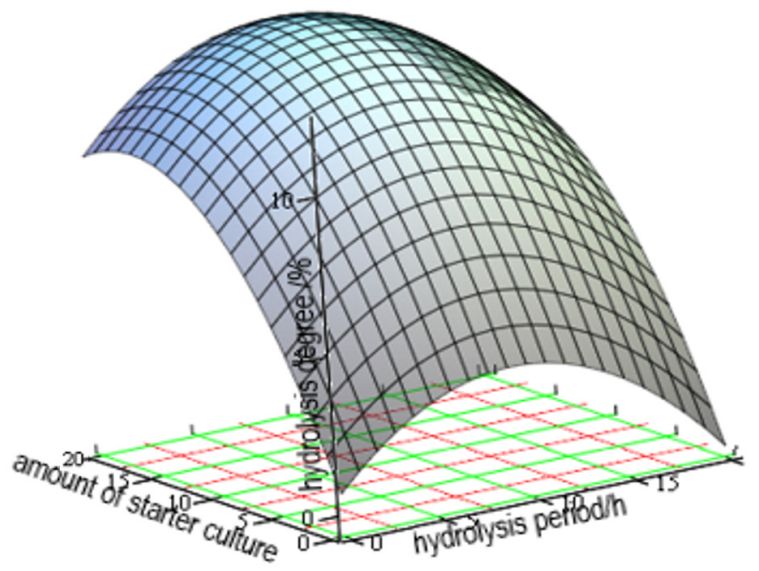

(c)

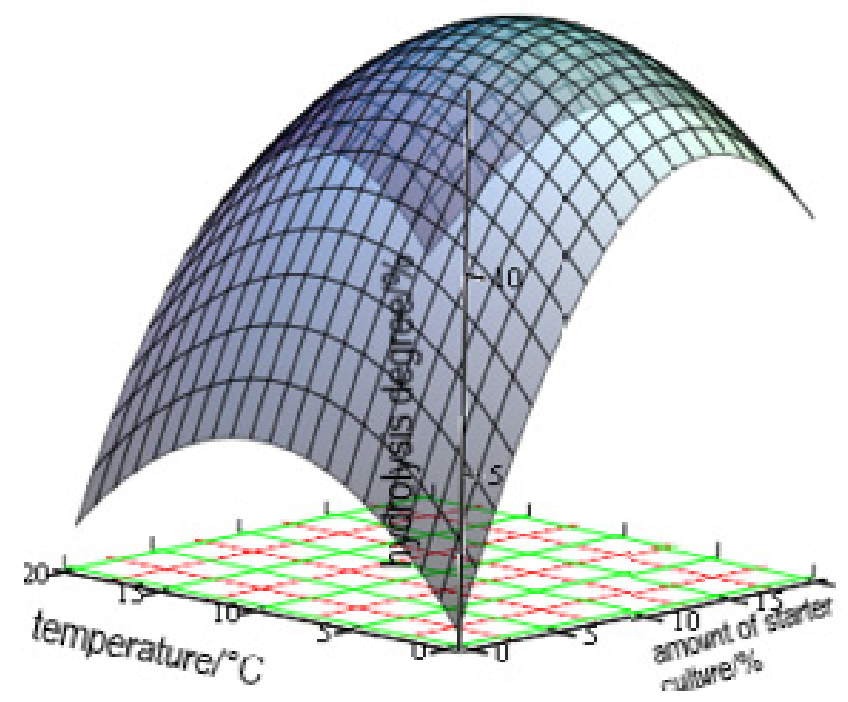

(b)

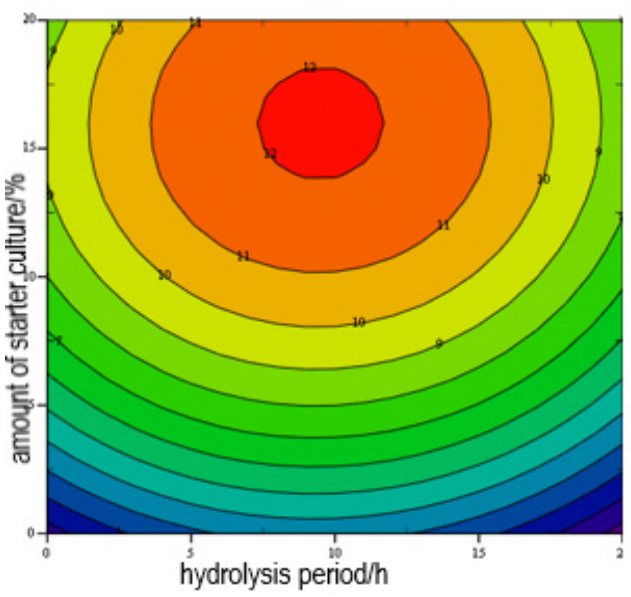

(d)

Figure 2. The 3D surface plots of hydrolysis degree of hen combs treated with BLC as a function of factors: (a) interactions of temperature and hydrolysis period on $\mathrm{DH} ;(\mathbf{b})$ interactions of temperature and the amount of bacterial concentrate; (c) interaction of the amount of bacterial concentrate and hydrolysis period on $\mathrm{DH}$; (d) contour plots of degree of hen combs hydrolysis as a function of interaction of the amount of bacterial concentrate and hydrolysis period on $\mathrm{DH}$.

\subsection{Chemical Properties}

Changes in the temperature and $\mathrm{pH}$ of the substrate can affect the proteolytic activity of exogenous enzymes and, as a consequence, can enhance the intensity of the biopolymers destruction [21]. The acidity of the biotechnological systems is formed as a result of the accumulation of fermentation products, primarily organic acids. The level of active and titratable acidity allows us to assess the intensity of the hydrolysis processes of poultry by-products.

When studying the dynamics of active acidity, it was found that the $\mathrm{pH}$ level after $12 \mathrm{~h}$ of hydrolysis at a temperature of $30^{\circ} \mathrm{C}$ reached $5.83-5.96$ under the action of propionic acid bacteria enzymes and 5.80-5.86 under the action of bifidobacteria enzymes.

The most significant acid accumulation during fermentation of hen combs was observed at temperatures of 35 and $40{ }^{\circ} \mathrm{C}$. Thus, at a temperature of $40{ }^{\circ} \mathrm{C}$, the $\mathrm{pH}$ values reached a level of 3.80-4.03 at the end of the hydrolysis process, and the concentration of bacterial starters did not significantly affect this indicator. If the hydrolysis proceeded at high temperatures, then the $\mathrm{pH}$ level decreased most intensively in the first $4 \mathrm{~h}-$ by 
26.6-28.5\% (Figure 3). The hydrolysis processes of the hen combs proceeded more efficiently, when treated with propionic acid bacteria compared to the fermentation under the bifidobacteria enzymes. Thus, within $12 \mathrm{~h}$ of fermentation with propionic bacteria, the titratable acidity reached values of $0.57-0.65$ degrees at $35^{\circ} \mathrm{C}$; and $0.74-0.82$ degrees-at $40{ }^{\circ} \mathrm{C}$ (Figure 4 ).

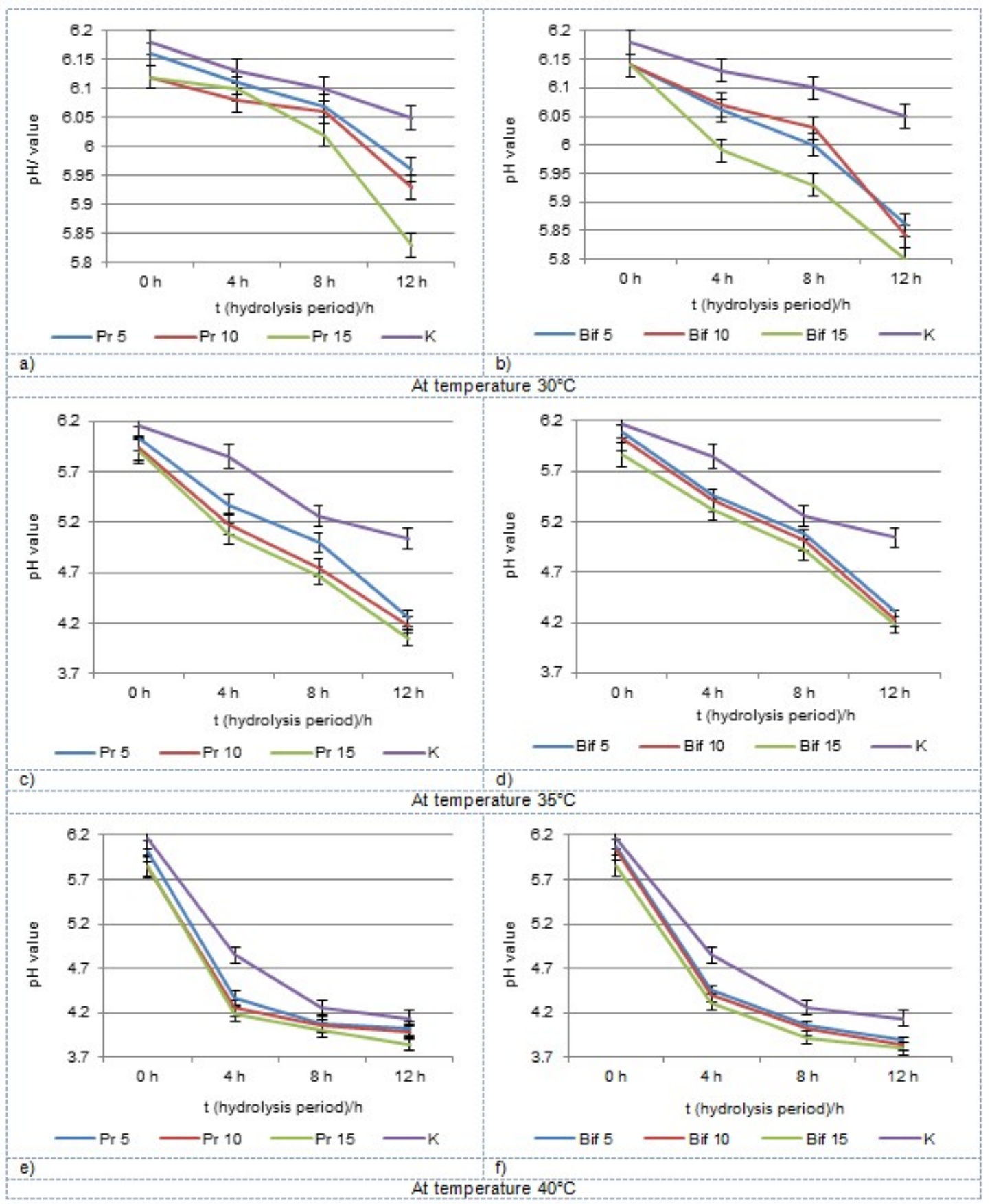

Figure 3. Dynamics of $\mathrm{pH}$ level of hen combs during the hydrolysis period $(\mathrm{t})$ : at temperature $30{ }^{\circ} \mathrm{C}$ (a) treated with BLC; (b) treated with Propionix LCSC; at temperature $35^{\circ} \mathrm{C}$ (c) treated with BLC; (d) treated with Propionix LCSC; at temperature $40^{\circ} \mathrm{C}$ (e) treated with BLC; (f) treated with Propionix LCSC. Each trial was performed in five replicates. The bars in the picture represent the standard deviation of each mean. 


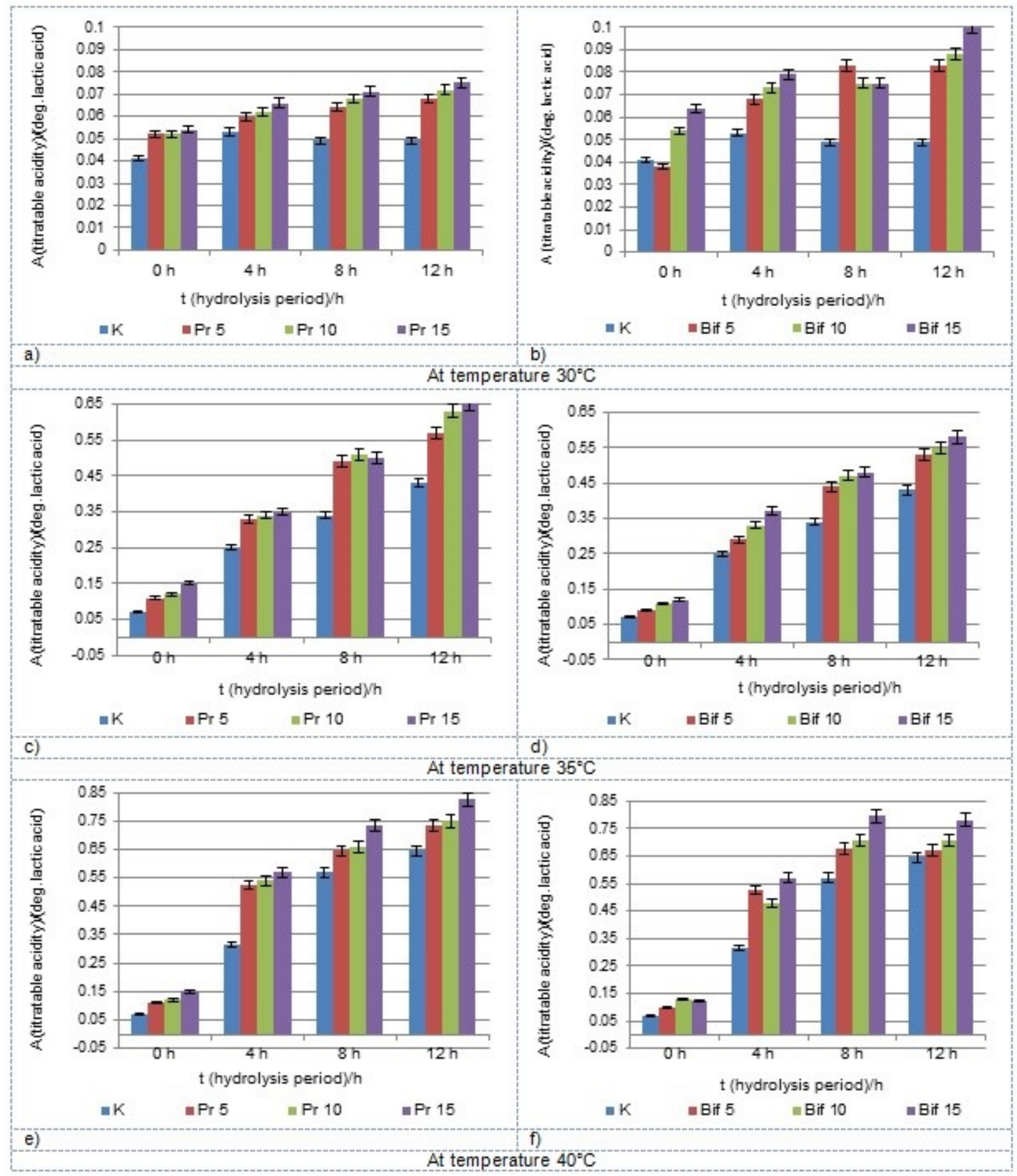

Figure 4. Dynamics of titratable acidity (A) of hen combs during the hydrolysis period (t): at temperature $30{ }^{\circ} \mathrm{C}$ (a) treated with BLC; (b) treated with Propionix LCSC; at temperature $35^{\circ} \mathrm{C}$ (c) treated with BLC; (d) treated with Propionix LCSC; at temperature $40{ }^{\circ} \mathrm{C}(\mathbf{e})$ treated with BLC; (f) treated with Propionix LCSC. Each trial was performed in five replicates. The bars in the picture represent the standard deviation of each mean.

The obtained data are consistent with the results of regression analysis of parameters for hen combs hydrolysis, where the optimal conditions of the fermentation process were established: temperature $39.7-43.4^{\circ} \mathrm{C}$, hydrolysis period-10.0-12.3 $\mathrm{h}$.

The authors noted that microbial proteases can interact with proteins in the fermented meat at a certain $\mathrm{pH}$ and temperature [22-24]. 


\subsection{Dispersed Composition, Free Amino Acids and Microstructure of the Comb Hydrolysates}

Studies of the dispersed composition of the comb hydrolysates have shown that the particle size in samples treated with bacterial concentrates decreased (Figure 5), which is associated with the cleavage of proteins into simpler peptides under the action of enzymes produced by microorganisms. Thus, the average particle size in the dispersed comb hydrolysate system decreased by $21 \%$ in the sample treated with bifidobacteria, and by $44 \%$ in the sample treated with propionic acid bacteria compared to control. Wilkins et al. [25] determined the correlation between the size of the molecule and the length of the polypeptide chain based on the measurement of the hydrodynamic radius of proteins. It was noted that the protein is cleaved by enzymes into peptides with different molecular weights and free amino acids [26,27].

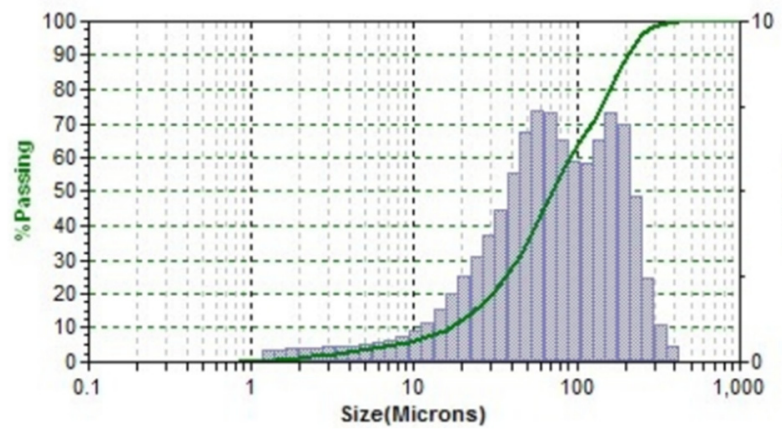

(a) $M N=(1.93 \pm 0.04)$ micron

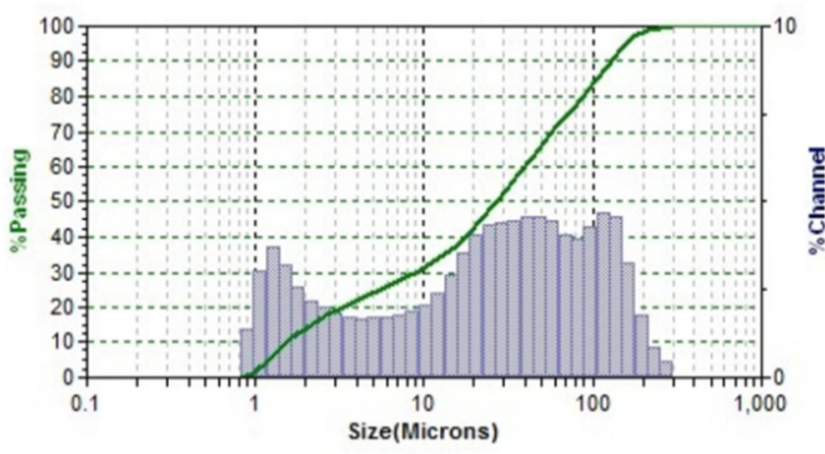

(c) $M N=(1.28 \pm 0.03)$ micron

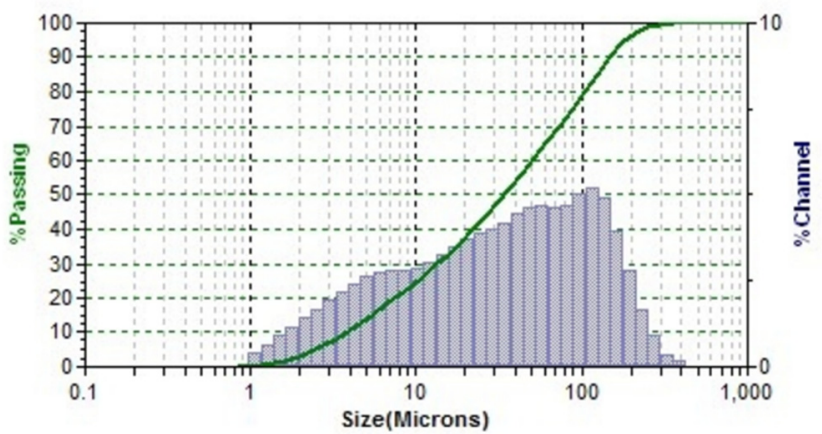

(b) $M N=(1.91 \pm 0.03)$ micron

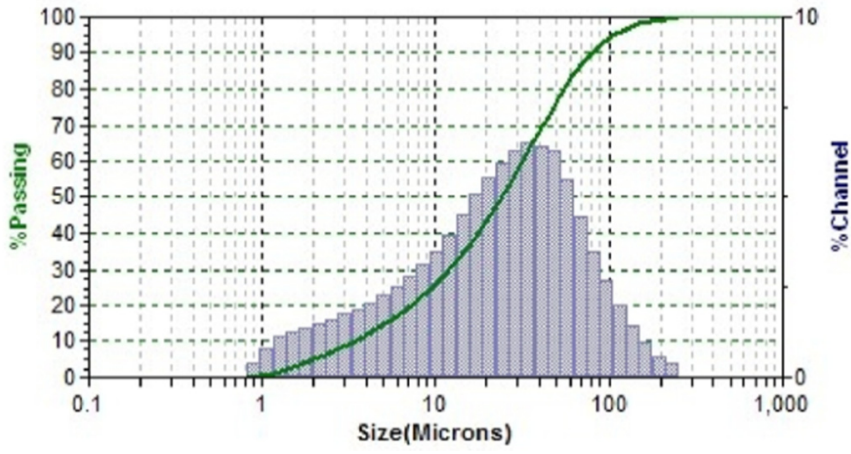

(d) $M N=(1.53 \pm 0.03)$ micron

Figure 5. The results of the dispersed composition evaluation of comb hydrolysates: (a) control sample in the start time; (b) hydrolyzed control sample; (c) hydrolyzed test sample with Propionix LCSC; (d) hydrolyzed test sample with BLC. MN-average hydrodynamic diameter determined from the numerical particle size distribution in hydrolysates. Results are represented as means $(n=5)$ \pm standard deviation.

This is consistent with our free amino acid results (Table 3), which showed an increase in free amino acids in fermented hen comb samples. Thus, the total amount of free amino acids in the samples fermented by propionic acid bacteria increased by $75 \%$, and by bifidobacterial-by $24 \%$. At the same time, there were more free essential amino acids after hydrolysis by bifidobacteria, in particular, such amino acids as methionine, phenylalanine, leucine and isoleucine. It has been noted that by-products contain essential amino acids such as lysine, methionine, and tryptophan [1].

The effect of various bacterial concentrate on the microstructural properties of the combs samples was observed at magnification 800 (Figure 6). 
Table 3. Content of the free amino acids in hen combs.

\begin{tabular}{cccc}
\hline Amino Acid (AA) & Control Sample & $\begin{array}{c}\text { Hydrolyzed Sample } \\
\text { with Propionix LCSC }\end{array}$ & $\begin{array}{c}\text { Hydrolyzed Sample } \\
\text { with BLC }\end{array}$ \\
\hline Aspa & $1.036 \pm 0.0093^{\mathrm{c}}$ & $2.238 \pm 0.0102^{\mathrm{a}}$ & $1.242 \pm 0.0107^{\mathrm{b}}$ \\
Glta & $3.464 \pm 0.0093^{\mathrm{b}}$ & $6.53 \pm 0.0114^{\mathrm{a}}$ & $3.212 \pm 0.0086^{\mathrm{c}}$ \\
Serine & not detected $^{\mathrm{a}}$ & $0.848 \pm 0.0124^{\mathrm{a}}$ & $0.18 \pm 0.0063^{\mathrm{b}}$ \\
Histidine & $3.58 \pm 0.0089^{\mathrm{c}}$ & $6.282 \pm 0.0073^{\mathrm{a}}$ & $4.034 \pm 0.0108^{\mathrm{b}}$ \\
Glycine & not detected $^{\mathrm{a}}$ & $2.03 \pm 0.0070^{\mathrm{a}}$ & $0.09 \pm 0.0071^{\mathrm{b}}$ \\
Threonine & $0.81 \pm 0.0109^{\mathrm{b}}$ & $0.852 \pm 0.0097^{\mathrm{a}}$ & $0.812 \pm 0.0073^{\mathrm{b}}$ \\
Arginine & $2.012 \pm 0.0058^{\mathrm{c}}$ & $7.35 \pm 0.0118^{\mathrm{a}}$ & $2.64 \pm 0.0927^{\mathrm{b}}$ \\
Alanin & $1.57 \pm 0.0084^{\mathrm{c}}$ & $3.574 \pm 0.0081^{\mathrm{a}}$ & $1.946 \pm 0.006^{\mathrm{b}}$ \\
Tyrosine & not detected $^{\mathrm{b}}$ & $1.564 \pm 0.006^{\mathrm{a}}$ & $1.442 \pm 0.0097^{\mathrm{b}}$ \\
Cystine & $3.046 \pm 0.0068^{\mathrm{b}}$ & $3.018 \pm 0.0073^{\mathrm{c}}$ & $3.162 \pm 0.0073^{\mathrm{a}}$ \\
Valine & $1.342 \pm 0.0102^{\mathrm{b}}$ & $1.614 \pm 0.006^{\mathrm{a}}$ & $1.61 \pm 0.0055^{\mathrm{a}}$ \\
Methionine & $1.654 \pm 0.0087^{\mathrm{b}}$ & $1.526 \pm 0.0081^{\mathrm{c}}$ & $1.774 \pm 0.006^{\mathrm{a}}$ \\
Phny & $1.876 \pm 0.0112^{\mathrm{b}}$ & $1.79 \pm 0.0095^{\mathrm{c}}$ & $2.142 \pm 0.0107^{\mathrm{a}}$ \\
Isoleucine & $1.654 \pm 0.0081^{\mathrm{c}}$ & $1.774 \pm 0.006^{\mathrm{b}}$ & $1.902 \pm 0.0102^{\mathrm{a}}$ \\
Leucine & $1.682 \pm 0.0086^{\mathrm{b}}$ & $1.464 \pm 0.0087^{\mathrm{c}}$ & $2.402 \pm 0.0073^{\mathrm{a}}$ \\
Proline & $1.858 \pm 0.0058^{\mathrm{c}}$ & $2.148 \pm 0.0049^{\mathrm{b}}$ & $2.904 \pm 0.0108^{\mathrm{a}}$ \\
Total AA & $25.45 \pm 0.1205^{\mathrm{c}}$ & $44.528 \pm 0.1270^{\mathrm{a}}$ & $31.51 \pm 0.0911^{\mathrm{b}}$ \\
\hline
\end{tabular}

Results are represented as means $(n=5) \pm$ standard deviation. Means in a row without a common superscript letter differ $(p<0.05)$ as analyzed by one-way ANOVA.

In the preparations of the control sample, cells and their nuclei are clearly visible, with a good perception of histological dyes. The extracellular matrix is represented by randomly located collagen fibers. In the deep tissues, layers of adipose tissue are visible, separated by thick connective tissue septa, consisting mainly of compactly packed collagen fibers (Figure 6(1a,1b)). In experimental samples treated with bacterial concentrates, the histological structure is clearly visualized. Compared to the control sample (Figure 6(2a)), attention is drawn to the reduced perception of histological dyes and the fuzziness of the connective tissue matrix, as well as fuzzy boundaries of cellular elements and their nuclei (Figure 6(3a,4a)). When stained with picro-fuchsin by the Van Gieson method, the experimental samples show a diffuse pinkish-crimson staining in all fields of view (Figure 6(3b,4b)).

In the control group, fields free of collagen fibers (for example, bundles of smooth muscle fibers) are colored yellow with picric acid (Figure 6(1b)). The noted phenomenon is associated with collagen hydrolysis and diffusion of the hydrolyzate through the tissue. Under the action of organic acids produced by lactic acid and propionic acid bacteria, collagen fibers swell and the raw materials soften [28].

A complex of proteolytic enzymes secreted by bacteria during metabolism promotes the breakdown of muscle and collagen fibers. The destructive effect of lactic acid on animal tissue was noted by Aktas and Kaya [29]. The beneficial effect of fermentation on the microstructure of animal tissues was identified by Rawdkuen and Benjakul [30]. Thus, the results of microstructural studies show that when combs are treated with bacterial concentrates, changes occur in the microstructure of connective tissue-the breakdown of collagen bundles into individual fibrils. 


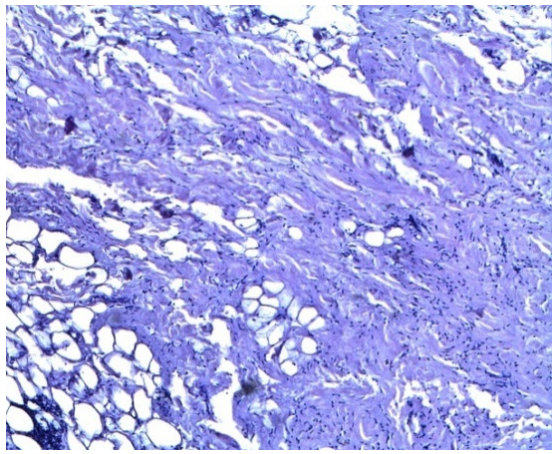

1a

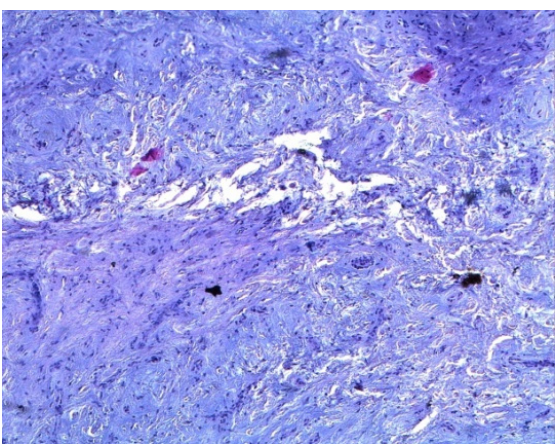

2a

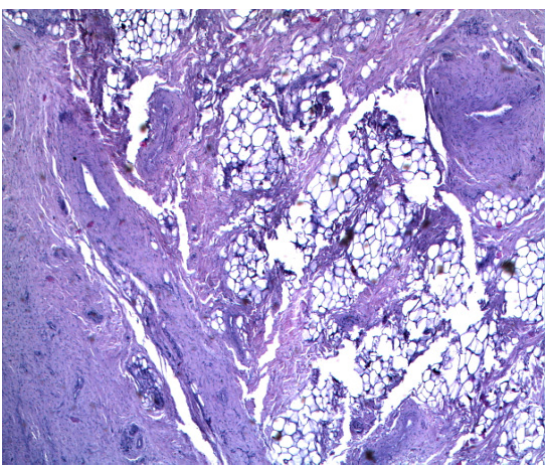

3a

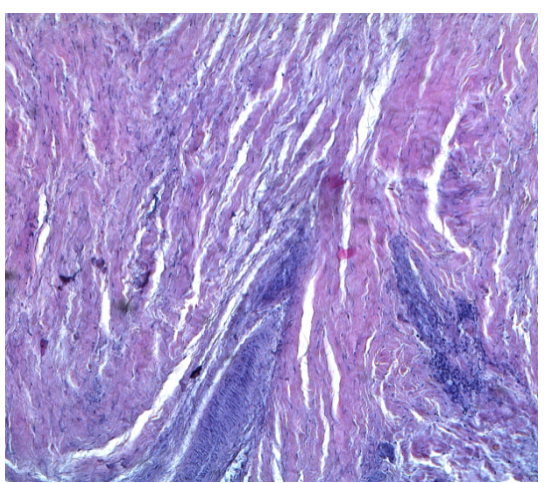

4 a

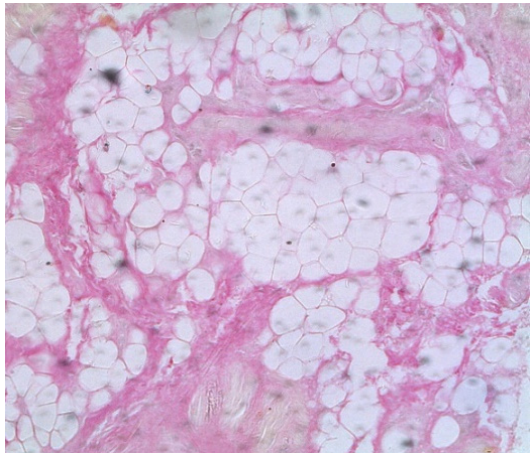

$1 \mathrm{~b}$
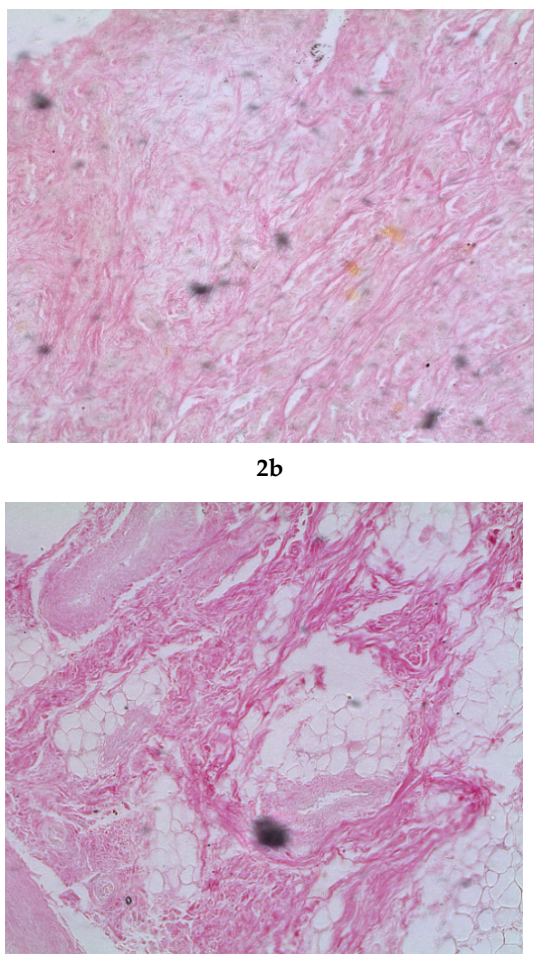

$3 b$

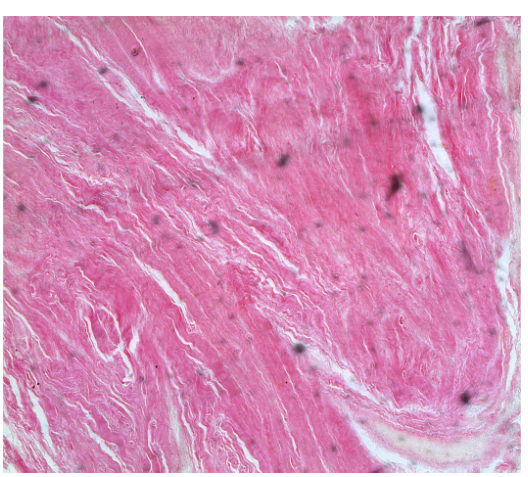

$4 b$

Figure 6. Microstructure of comb hydrolysates: (1) control sample in the start time; (2) hydrolyzed control sample; (3) hydrolyzed test sample with Propionix LCSC; (4) hydrolyzed test sample with BLC. Staining method: (a) hematoxylin-eosin; (b) according to Van Gieson. Magnification $\times 800$.

\section{Conclusions}

The results of the study showed that the fermentation with a concentrates of bifidobacteria and propionic acid bacteria has a positive effect on the hydrolysis of hen combs. Multiple regression equations and response surface methodology was used to describe the 
process of hydrolysis of hen combs to determine the optimal hydrolysis parameters. All technological parameters have a significant impact on the degree of hydrolysis. A higher temperature and a longer hydrolysis period increased the level of hydrolysis, while the effect of the amount of bacterial concentrate depended on the type of microorganisms.

The results of biochemical, microscopic and dispersed analysis confirm the combs hydrolyzability due to an increase in the $\mathrm{pH}$ level and titratable acidity, changes in structural components, and an increase in the amount of smaller protein particles.

This study illustrates that hydrolysates derived from hen by-products might become a potential protein source as functional ingredients in food systems.

Author Contributions: Conceptualization, O.Z.; methodology, O.Z. and S.M.; investigation, O.Z., S.M., M.R., P.B. and A.K.; data curation and analysis, O.Z., S.M. and G.Z.; supervision, O.Z.; writingoriginal draft, O.Z. and S.M.; writing-article and editing O.Z. and S.M. All authors have read and agreed to the published version of the manuscript.

Funding: The research was funded by a grant of the Ministry of Science and Higher Education of the Russian Federation for large scientific projects in priority areas of scientific and technological development (subsidy identifier 075-15-2020-775).

Institutional Review Board Statement: Not applicable.

Informed Consent Statement: Not applicable.

Data Availability Statement: Data will be made available up on request to the corresponding author.

Acknowledgments: We would like to thank managers of Scientific and Educational Center of Nanotechnology of South Ural State University for their technical support during this work.

Conflicts of Interest: The authors declare no conflict of interest. The funders had no role in the design of the study; in the collection, analyses, or interpretation of data; in the writing of the manuscript, or in the decision to publish the results.

\section{References}

1. Mullen, A.M.; Álvarez, C.; Zeugolis, D.I.; Henchion, M.; O’Neill, E.; Drummond, L. Alternative uses for co-products: Harnessing the potential of valuable compounds from meat processing chains. Meat Sci. 2017, 132, 90-98. [CrossRef] [PubMed]

2. Brandelli, A.; Sala, L.; Kalil, S.J. Microbial enzymes for bioconversion of poultry waste into added-value products. Food Res. Int. 2015, 73, 3-12. [CrossRef]

3. Ahmad, T.; Ismail, A.; Ahmad, S.A.; Khalil, K.A.; Kumar, Y.; Adeyemi, K.D.; Sazili, A.Q. Recent advances on the role of process variables affecting gelatin yield and characteristics with special reference to enzymatic extraction: A review. Food Hydrocoll. 2017, 63, 85-96. [CrossRef]

4. Toldrá, F.; Reig, M.; Mora, L. Management of meat by- and co-products for an improved meat processing sustainability. Meat Sci. 2021, 181, 108608. [CrossRef] [PubMed]

5. Iwaniak, A.; Minkiewicz, P.; Darewicz, M.; Hrynkiewicz, M. Food protein originating peptides as tastants-physiological, technological, sensory, and bioinformatic approaches. Food Res. Int. 2016, 89, 27-38. [CrossRef]

6. Toldrá, F.; Reig, M.; Aristoy, M.C.; Mora, L. Generation of bioactive peptides during food processing. Food Chem. 2018, 267, 395-404. [CrossRef]

7. Herregods, G.; Camp, J.V.; Morel, N.; Ghesquière, B.; Gevaert, K.; Vercruysse, L.; Dierckx, S.; Quanten, E.; Smagghe, G. Angiotensin I-converting enzyme inhibitory activity of gelatin hydrolysates and identification of bioactive peptides. J. Agric. Food Chem. 2011, 59, 552-558. [CrossRef]

8. Verma, A.K.; Chatli, M.K.; Kumar, P.A.V.A.N.; Mehta, N. Antioxidant and antimicrobial activity of protein hydrolysate extracted from porcine liver. Indian J. Anim. Sci. 2017, 87, 711-717.

9. Borrajo, P.; Pateiro, M.; Barba, F.J.; Mora, L.; Franco, D.; Toldrá, F.; Lorenzo, J.M. Antioxidant and Antimicrobial Activity of Peptides Extracted from Meat By-products: A Review. Food Anal. Meth. 2019, 12, 2401-2415. [CrossRef]

10. Adhikari, B.B.; Chae, M.; Bressler, D.C. Utilization of slaughterhouse waste in value-added applications: Recent advances in the development of wood adhesives. Polymers 2018, 10, 176. [CrossRef]

11. Bezerra, T.; Estévez, M.; Lacerda, J.T.; Dias, M.; Juliano, M.; Mendes, M.A.; Morgano, M.; Pacheco, M.T.; Madruga, M. Chicken Combs and Wattles as Sources of Bioactive Peptides: Optimization of Hydrolysis, Identification by LC-ESI-MS2 and Bioactivity Assessment. Molecules 2020, 25, 1698. [CrossRef] [PubMed]

12. Ryder, K.; Bekhit, A.E.D.; McConnell, M.; Carne, A. Towards generation of bioactive peptides from meat industry waste proteins: Generation of peptides using commercial microbial proteases. Food Chem. 2016, 208, 42-50. [CrossRef] [PubMed] 
13. Zinina, O.; Merenkova, S.; Soloveva, A.; Savostina, T.; Sayfulmulyukov, E.; Lykasova, I.; Mizhevikina, A. The effect of starter cultures on the qualitative indicators of dry fermented sausages made from poultry meat. Agron. Res. 2018, 16, $2265-2281$.

14. Merenkova, S.; Zinina, O.; Loretz, O.; Neverova, O.; Sharaviev, P. Effect of transglutaminase and bacterial concentrates on the development of functional and technological properties of minced meat. Pol. J. Food Nutr. Sci. 2019, 69, 387-396. [CrossRef]

15. Hong, H.; Fan, H.; Chalamaiah, M.; Wu, J. Preparation of low-molecular-weight, collagen hydrolysates (peptides): Current progress, challenges, and future perspectives. Food Chem. 2019, 301, 125222. [CrossRef] [PubMed]

16. Teshnizi, Z.M.; Robatjazi, S.M.; Mosaabadi, J.M. Optimization of the Enzymatic Hydrolysis of Poultry Slaughterhouse Wastes Using Alcalase Enzyme for the Preparation of Protein Hydrolysates. Appl. Food Biotechnol. 2020, 7, $153-160$.

17. Assaad, H.; Zhou, L.; Carroll, R.J.; Wu, G. Rapid publication-ready MS-Word tables 597 for one-way ANOVA. SpringerPlus 2014, 3, 474. [CrossRef]

18. Santos, B.A.S.; Azambuja, S.P.H.; Ávila, P.F.; Pacheco, M.T.B.; Goldbeck, R. n-Butanol production by Saccharomyces cerevisiae from protein-rich agro-industrial by-products. Braz. J. Microbiol. 2020, 51, 1655-1664. [CrossRef]

19. Kurozawa, L.; Park, K.; Hubinger, M. Optimization of the enzymatic hydrolysis of chicken meat using response surface methodology. J. Food Sci. 2008, 73, 405-412. [CrossRef]

20. Lindberg, D.; Kristoffersen, K.A.; Vogel-van den Bosch, H.; Wubshet, S.G.; Böcker, U.; Rieder, A.; Nils, E.F.; Afseth, K. Effects of poultry raw material variation and choice of protease on protein hydrolysate quality. Process. Biochem. 2021, 110, 85-93. [CrossRef]

21. Lafarga, T.; Hayes, M. Bioactive peptides from meat muscle and by-products: Generation, functionality and application as functional ingredients. Meat Sci. 2014, 98, 227-239. [CrossRef] [PubMed]

22. Sun, F.; Sun, Q.; Zhang, H.; Kong, B.; Xia, X. Purification and biochemical characteristics of the microbial extracellular protease from Lactobacillus curvatus isolated from Harbin dry sausages. Int. J. Biol. Macromol. 2019, 133, 987-997. [CrossRef] [PubMed]

23. Sun, F.; Tao, R.; Liu, Q.; Wang, H.; Kong, B. Effects of temperature and pH on the structure of a metalloprotease from Lactobacillus fermentum R6 isolated from Harbin dry sausages and molecular docking between protease and meat protein. J. Sci. Food Agric. 2021, 101, 5016-5027. [CrossRef] [PubMed]

24. Thoresen, P.P.; Alvarez, R.G.; Vaka, M.R.; Rustad, T.; Sone, I.; Fernandez, E.N. Potential of innovative pre-treatment technologies for the revalorisation of residual materials from the chicken industry through enzymatic hydrolysis Innovative. Food Sci. Emerg. Technol. 2020, 64, 102377. [CrossRef]

25. Wilkins, D.K.; Grimshaw, S.B.; Receveur, V.; Dobson, C.M.; Jones, J.A.; Smith, L.J. Hydrodynamic Radii of Native and Denatured Proteins Measured by Pulse Field Gradient NMR Techniques. Biochemistry 1999, 38, 16424-16431. [CrossRef]

26. Hou, Y.; Wu, Z.; Dai, Z.; Wang, G.; Wu, G. Protein hydrolysates in animal nutrition: Industrial production, bioactive peptides, and functional significance. J. Anim. Sci. Biotechnol. 2017, 8, 24. [CrossRef]

27. Glomm, W.R.; Wubshet, S.G.; Lindberg, D.; Dankel, K.R.; Afseth, N.K.; Stenstad, P.M.; Johnsen, H. Immobilized protease on magnetic particles for enzymatic protein hydrolysis of poultry by-products. LWT 2021, 152, 112327. [CrossRef]

28. Biavati, B.; Vescovo, M.; Torriani, S.; Bottazzi, V. Bifidobacteria: History, ecology, physiology and applications. Ann. Microbiol. 2000, 50, 117-131.

29. Aktas, N.; Kaya, M. The influence of marinating with weak organic acids and salts on the intramuscular connective tissue and sensory properties of beef. Eur. Food Res. Technol. 2001, 213, 88-94. [CrossRef]

30. Rawdkuen, S.; Benjakul, S. Biochemical and microstructural characteristics of meat samples treated with different plant proteases. Afr. J. Biotechnol. 2012, 11, 14088-14095. [CrossRef] 